\section{REFERÊNCIAS BIBLIOGRAFICAS}

1. LEBRUN, G., La patience du concept, Paris, Gallimard, 1972.

2. MERLEAU-PONTY, M. Le visible et l'invisible, trad. Gianotti, Editora Perspectiva, 1992.

3. PRADO JR., Bento, Erro, ilusão, loucura, São Paulo: Editora 34, 2004.

4._ Presença e campo transcendental, São Paulo: Edusp, 1988.

5. SARTRE, L'être et le néant. Paris: 1943.

\section{The philosopher's presence}

Abstract: This paper pays tribute to the Bento Prado's work, stressing the originality and the critical aspect of his philosophical posture. In this sense, it analyses the strength of the concept of "Presence" - central axis of the author's doctoral thesis, published with the title Presence and transcendental field - which is able to design in an unheard-of manner a point of convergence between the philosophies of Bergson, Sartre and Merleau-Ponty.

Keywords: Bento Prado Jr, Presence, Bergson, Merleau-Ponty, Sarte, phenomenology.

\section{NOTAS}

1. Agradeço a Cristiano Perius essa referência.
A “GRANDE POLÍTICA" OU MERLEAU-PONTY LEITOR DE

MAQUIAVEL

\section{Leandro Neves Cardim*}

Resumo: Este artigo pretende abordar a obra de Nicolau Maquiavel principalmente a partir da leitura feita por Maurice Merleau-Ponty. Para isto, apresentaremos, em um primeiro momento, alguns traços gerais da filosofia política merleau-pontiana com o intuito de rastrear a presença de Maquiavel no espectro de sua obra. Tratar-se-á, também, de indicar as balizas que guiam MerleauPonty na leitura de um texto filosófico. Quanto à discussão da filosofia maquiaveliana, procuraremos, em seguida, destacar os pontos que fizeram do secretário florentino o primeiro pensador político moderno, momento em que teremos a oportunidade de explicitar a interpretação de Merleau-Ponty Para concluir, serão colocados em relevo os aspectos que, segundo a expressão de Claude Lefort, fazem com que a política em Maquiavel seja compreendida como "grande política".

Palavras-chave: Merleau-Ponty, Maquiavel, Lefort, humanismo, política.

Ao abordar os textos dos filósofos clássicos, Merleau-Ponty não retoma as grandes questões da filosofia tornando-as pequenas, ele não as reduz aproximando-as de algum cânone ideal e unívoco. Trata-se, para ele, de retomar certas questões que o ajudam a pensar o mundo em que vivemos. Sua intenção expressa é "fazer no nosso tempo, e através da nossa experiência, o que os clássicos fizeram no seu” (Merleau-Ponty 12, p.70) Ora, quando um pensador interroga a obra de um outro pensador e encontra uma resposta que ainda é fecunda, tal interrogação e resposta são determinadas tanto pelo modo como o filósofo vive a apreensão do passado e do presente quanto pela maneira com que exprime suas próprias preocupações. Donde o aprendizado que cada filosofia pode nos oferecer, com a ressalva de que saibamos extrair, da maneira com que manifestaram e responderam suas preocupações, uma maneira de manifestarmos e respondermos as nossas próprias preocupações nascidas de uma leitura do presente (cf. Silva 20). ${ }^{1}$

Ao ler um autor clássico precisamos reconhecer uma historicidade que os alimenta por dentro: o sentido que sua obra oferece é aberto e pode ser retomado. Além 
disto, se "queremos ir mais longe", é preciso compreender que há obras que:

“continuam falando além dos enunciados, das proposições, intermediários obrigatórios. [...] Assim são os clássicos. Reconhecemo-los pelo fato de ninguém os tomar ao pé da letra, e de, mesmo assim, os fatos novos nunca estarem totalmente fora de sua competência, de se tirarem deles novos ecos e de se revelarem neles novos relevos" (Merleau-Ponty 13, p.16-17).

O sentido no qual empregamos a palavra "clássico" não consiste naquele sentido primeiro e tradicional. Costumamos chamar de clássicos aqueles autores para quem "a racionalidade em si do mundo é inquestionável”, ou ainda, alguém que pensa a criação humana como uma verdade depositada no mundo (cf. Merleau-Ponty 13, p.243 e 242). Para nós, clássico é aquele autor ou obra que, sedimentados sob os escombros do mundo cultural, ainda nos faz pensar e que, por isto mesmo, nos dá a pensar. O texto de Merleau-Ponty sobre Maquiavel é um texto assim. Além de suscitar uma posteridade, ele ainda nos interpela, pois procurando responder a questões que eram bastante pontuais, as transcende.

O campo conceitual no interior do qual se dá o debate é o da filosofia política e da filosofia da história. Os conceitos são vários e a situação no interior da qual foi concebido tanto o texto de Merleau-Ponty quanto o de Maquiavel é muito peculiar. Aliás, é precisamente isto que faz a inovação da postura destes filósofos, pois ambos ensaiaram respostas novas a questões também novas. Só que para isto, eles não foram buscar respostas em princípios transcendentes, mas na observação do mundo real. Procuraremos explicitar na leitura de Merleau-Ponty aquilo que fez a novidade de Maquiavel, a saber, aquilo que fez do secretário florentino o primeiro pensador político moderno. Talvez assim consigamos reativar não só os horizontes da filosofia maquiaveliana, mas também os horizontes da filosofia merleau-pontiana. Trata-se, portanto, de haurir da leitura de Maquiavel feita por Merleau-Ponty menos uma reflexão sobre seu itinerário filosóficopolítico, e mais algo que ainda nos ensine a interrogar a realidade do social, da política, da história e do poder.

$\mathrm{O}$ texto de Merleau-Ponty foi composto com o intuito de ser apresentado em setembro de 1949 em uma comunicação intitulada Maquiavelismo e humanismo no "Congresso de Humanismo e de Ciência Política" que se passou tanto em Roma quanto em Florença. O texto apresentado em Signos foi, primeiramente, publicado na revista $O s$ tempos modernos no mesmo ano e já com o título que conhecemos hoje. A "Nota sobre Maquiavel" foi composta com o pano de fundo da "guerra fria", a qual aparece como que em baixo relevo durante todo o texto. O livro Humanismo e terror escrito em 1947 já era fruto da situação mundial onde Merleau-Ponty procurava, "no dia seguinte da guerra", "formular uma atitude de attentisme [espera] marxista" (Merleau-Ponty 14, p.316). Se o marxismo se mantinha apesar da situação de espera mundial, isto se dava porque,

"reconduzido ao essencial, o marxismo não é uma filosofia otimista - é somente a idéia de que uma outra história é possível, que não há destino e que a existência é aberta. É a tentativa resoluta por este futuro que ninguém no mundo, nem fora do mundo, sabe se será ou não será" (Merleau-Ponty 15, p.209). ${ }^{2}$

O que está em jogo, aqui, é que a filosofia política que se trata de esboçar procura manter juntas tanto a possibilidade da emancipação quanto da barbárie. E como não temos um solo universal que possa garantir o sucesso da ação, é preciso caminhar como quem dá passos em brumas. No Prefácio de Sentido e não-sentido escrito em 1948 percebemos claramente que foi a situação do mundo em que vivia que o obrigou a "evocar o fundo de não-senso sobre o qual se delineia toda empreitada histórica, e que a ameaça de impasse" (Merleau-Ponty 15, p.9). Este era o contexto no qual foi escrito a "Nota sobre Maquiavel", nesta época a política marxista havia "perdido confiança em sua própria audácia, ela [havia] abandonado seus próprios meios proletários e retomado aqueles da história clássica: hierarquia, obediência, desigualdade, diplomacia, polícia” (Merleau-Ponty 15, 9-10). Esperava-se que quando a guerra chegasse ao fim o espírito do marxismo reapareceria e o movimento das massas americanas substituiria a revolução russa. Mas não; ele nos diz que esta esperança foi decepcionada, pois no momento mesmo em que ele escreve encontram-se

“face a face uma América quase unânime na caça aos ‘vermelhos', 
com as hipocrisias que a crítica marxista desvelou na consciência liberal, e uma União Soviética que toma por fato realizado a divisão de um mundo em dois campos, por inevitável a solução militar, não conta com nenhum despertar da liberdade proletária, mesmo e sobretudo quando ela aventura os proletários nacionais em missões de sacrifício" (Merleau-Ponty, 15 p.10).

Os cidadãos daqueles dias não tinham certeza se o mundo humano seria possível, todavia, ainda assim o impasse não poderia ser considerado fatal. Era preciso ganhar do acaso, o que só seria possível se os homens de ação pudessem medir o risco e a tarefa. $\mathrm{O}$ risco consistia na possibilidade de que a crise se tornasse mais radical, enquanto a tarefa a ser enfrentada se expressava na própria consideração daquilo que nosso filósofo chamava de "nova idéia de razão", onde "a mais alta idéia de razão é vizinha da desrazão" (Merleau-Ponty 15, p.9).

A "Nota sobre Maquiavel" foi concebida no contex to daquilo que se convencionou chamar da primeira filosofia de Merleau-Ponty, mas em toda a obra do filósofo a presença da filosofia maquiaveliana pode ser matizada como uma das balizas de seu pensamento político-histórico. Se de acordo com a primeira etapa da filosofia merleau-pontiana é preciso agir na incerteza relativa ou em uma espécie de inquietude própria a nossa condição (cf. Merleau-Ponty 16, p.76), e ainda assim, sob o risco de nos enganarmos donde a predominância da "espera" em relação à opressão stalinista -, também em As aventuras da dialética, Maquiavel será um dos autores que balizará a posição política de Merleau-Ponty, que, agora, não será nem comunista, nem anticomunista. Movido por novos problemas, ${ }^{3}$ ele é levado a falar, para abordar as questões da história e da política, tanto de uma "esquerda não-comunista" quanto de um "novo liberalismo" (MerleauPonty 14, p.312). ${ }^{4}$ Bem entendido, não se trata, de forma alguma, de "uma solução". No Epílogo escrito entre 1953 e 1954 ele nos diz que

"se estava apenas começando a conhecer o social e, aliás, um sistema de vidas conscientes nunca admitirá uma solução como as palavras cruzadas ou os problemas elementares de aritmética. Tratase, antes, da resolução de segurar nas mãos as duas pontas da cadeia, o problema social e a liberdade" (Merleau-Ponty 14, p.314).
Neste período, nosso filósofo já terá se desembaraçado da "ilusão" de caráter marxista que consistia em fazer "do nascimento e do crescimento do proletariado, a significação total da história" (Merleau-Ponty 14, p.284). Em 1955, não há mais, para a política, um mapa, mas ela ainda será feita em vista do presente (cf. Merleau-Ponty 14, p.12), "em contato com os acontecimentos", que, todavia, devem ser "ocasião de tomada de consciência" (Merleau-Ponty 14, p.319). E isto, porque "não há mais um núcleo da história", mas, sim, "mais de uma dimensão, mais de um plano de referência, mais de uma fonte de sentido" (Merleau-Ponty 14, p.18). As escolhas políticas de Merleau-Ponty sempre estarão ligadas à especificidade dos contextos que ele atravessa, donde a retomada de Maquiavel no último parágrafo do Prefácio de Signos escrito em 1960. Se for preciso ter "virtù sem nenhuma resignação" (Merleau-Ponty 13, p.47), é porque "não há relógio universal”, mas "histórias locais [que] começam, sob os nossos olhos, a adquirir força, e começam a regular-se a si mesmas, e tateando ligam-se uma a outra" (Merleau-Ponty 13, p.47). ${ }^{5}$

Merleau-Ponty não revisa, nem sobrevoa ou inspeciona intelectualmente os textos de Maquiavel, mas também não se trata de identificar-se completamente com eles. Ele se vale da obra maquiaveliana como algo que lhe ensina a pensar e, fazendo isto, temos a oportunidade de explorar seu texto como alguém que está trabalhando. Em relação aos textos que lê, poderíamos dizer que ele pratica uma espécie de redução em proveito de uma experiência da leitura que procura apreender o filósofo se fazendo. Ele põe entre parênteses as duas maneiras tradicionais de abordar uma obra: a objetivista e subjetivista. Por um lado, ele exclui a pura exterioridade existente entre o sujeito e objeto. Esta postura termina abordando a obra como um conjunto coeso de proposições positivas, pois, no limite, se trataria, apenas, de extrair a coerência lógica da argumentação, onde a obra estaria pura e simplesmente nos textos a serem lidos. Por outro lado, ele também exclui a absoluta coincidência onde o intérprete seria o todo poderoso, momento da eliminação das diferenças intrínsecas, já que haveria atribuição de valor apenas aos infinitos trabalhos da posteridade. Estes dois prejuízos têm um imenso pressuposto comum, a saber: a obra é sempre inteiramente determinada, ela é tida por um objeto em si tomado por verdadeiro graças à possibilidade de sempre receber apenas um sentido. A filosofia em questão seria passível de uma determinação unívoca, pois não passaria de um 
objeto ou idéia plenamente determinada. Não se trata de ater-se ao resultado daquilo que uma obra se tornou. É verdade que ele não desconsidera nem a posteridade, ou melhor, o debate instaurado pela obra, nem a própria obra do autor em questão, já que é do interior deste campo que a discussão se dá. Merleau-Ponty mergulha radicalmente no texto de Maquiavel, mas também dá voz a leitores que também se debruçaram sobre os textos em questão. ${ }^{6}$ Como sempre, o essencial de uma obra bem-sucedida está na interrogação do autor no trabalho, pois é neste momento que algo excede aquilo que foi dito de modo explícito. Este próprio excesso é que dá algo a ser pensado, pois uma obra de filosofia nunca pode ser considerada como um objeto passível de ser dominado inteiramente, seja do ponto de vista objetivo, seja do subjetivo. A maneira com que Merleau-Ponty aborda a obra maquiaveliana é fecunda porque, quando se trata de ler uma filosofia, é preciso fazêla falar. E ao fazer isto, sua leitura ou interrogação também nos dá a falar. ${ }^{7}$

II

O Maquiavel que surge das páginas merleau-pontianas é alguém que procura trilhar um caminho no contato com seu próprio tempo, mas é, também, um filósofo que sofre uma espécie de degradação ou sedimentação junto a seus leitores. Como encontrar aquele Maquiavel que não é maquiavélico sob os próprios textos que chegaram até nós? Como compreender que esta interpretação é justificada não pelos textos de Maquiavel, mas pela fortuna crítica que suscitou? Como compreender que a filosofia de Maquiavel não seja nem um humanismo puro, nem um moralismo puro, ambos fora da história e das relações sociais abarrotadas de ambigüidades e reviravoltas? Dizer que Maquiavel seja maquiavélico é uma maneira de "desaprovar" sua obra, é “o impiedoso estratagema daqueles que dirigem os seus olhos e os nossos para o céu dos princípios para desviá-los do que fazem" (Merleau-Ponty 13, p.252). Se o adjetivo "maquiavélico" e o substantivo "maquiavelismo" chegaram até nós como sinônimo de uma conduta diabólica, foi porque a filosofia de Maquiavel se contrapôs de maneira radical a tradição que via no poder algo sacro. Merleau-Ponty termina seu ensaio criticando esta postura tradicional e chamando a atenção para aquilo que segundo ele há de interessante na obra do escritor florentino: "há uma maneira de elogiar Maquiavel que é exatamente o contrário do maquiavelismo, já que enaltece em sua obra uma contribuição para a clareza política" (Merleau-Ponty 13, p.252). A clareza em política seria precisamente a descoberta de que a política não é aquilo que a tradição diz. A política deve ser entendida como relação com outrem no mundo real, ou melhor, a política deve ser compreendida como algo humano. Vem daí que a condenação da obra de Maquiavel como maquiavélica não passar de um prejuízo muito profundo e contra o qual o próprio autor florentino lutou bravamente, a saber: o preconceito teológico. Para compreender a situação dos acusadores de Maquiavel o texto de Merleau-Ponty nos mostra que, por um lado, encontramos aqueles que costumeiramente chamamos de "belas almas" ingênuas que sacrificam a ação, por outro, aqueles que separaram radicalmente a política das preocupações éticas negando os valores. O prejuízo em comum destes detratores consiste em que ambos recusam perceber a relação estreita entre política e moral. Para que a política seja efetiva é preciso que haja relação com o mundo dos acontecimentos. Maquiavel quer "escrever algo útil" para quem o ler. Para ele é "mais conveniente procurar a verdade efetiva das coisas do que o que se imaginou sobre elas" (Maquiavel 9, p.73). Tendo entrevisto as ambigüidades e as possibilidades da ação política, Maquiavel é um pensador da moral em política que parte da experiência concreta de seu próprio tempo.

Segundo Maquiavel, é verdade que o príncipe deve ter as qualidades que ele aparenta ter. Merleau-Ponty vê aí uma condição fundamental da política. Qual seja? A política deve "se desenrolar na aparência" (Merleau-Ponty 13, p.273-74). Todavia, para Maquiavel o príncipe tem que ter domínio de si para poder desenvolver os contrários quando isto for preciso. Se ele não puder ter as qualidades necessárias para o bom governo ele deve agir de tal forma que os comandados acreditem que ele as possui. Merleau-Ponty interpreta este pensamento como um preceito de política que poderia tornar-se a "regra de uma verdadeira moral" (Merleau-Ponty 13, p.274). Mas, atenção: não se trata de negar que tais qualidades não sejam essenciais para quem exerce o poder; também não se trata de dizer que a representação das qualidades deva ser simples simulacros pervertidos. O sentido deste pensamento está em que no terreno da política não há lugar para os valores próprios a uma moral abstrata. Ora, a política depende, sim, de avaliações morais, afinal, os homens julgam sempre a partir de valores herdados pela tradição. ${ }^{8} \mathrm{Na}$ verdade, Maquiavel tem boas razões para subtrair a política ao puro juízo moral. E isto, porque, 
em princípio, não podemos querer ser honestos no meio de gente desonesta, pois mais cedo ou mais tarde terminaríamos por perecer. Argumento que Merleau-Ponty considera fraco, pois ele poderia ser "aplicado à vida privada, onde Maquiavel permanece "moral" (Merleau-Ponty 13, p.272-73). Há, porém, um segundo argumento que pode levar mais longe: "é que, na ação histórica, a bondade é, às vezes, catastrófica e a crueldade menos cruel que um temperamento indulgente" (Merleau-Ponty 13, p.273). É neste sentido que a bondade deve estar relacionada com a dureza, pois uma bondade que não for capaz de ser dura envereda no desprezo de outrem, já que seria "uma maneira doce de ignorar outrem e finalmente de desprezá-lo" (Merleau-Ponty 13, p.275). Embora os homens não consigam discernir a verdade daquilo que o príncipe lhes fala, a capacidade de bem agir na cena pública, ou melhor, a virtù política que Merleau-Ponty quer apreender em Maquiavel, consiste em que o príncipe deve "falar a seus espectadores mudos em torno dele e tomados na vertigem da vida em comum" (Merleau-Ponty 13, p.275). Portanto, entre a pura e simples vontade de agradar e o desafio radical, o príncipe deve conceber uma "empreitada histórica à qual todos podem se juntar" (Merleau-Ponty 13, p.275). Enfim, para Maquiavel, é a relação com outrem que deve ser tomada como "signo de valor na política".

"Pelo domínio de suas relações com outrem, o poder transpõe os obstáculos entre o homem e o homem e coloca alguma transparência nas nossas relações, - como se os homens não pudessem estar próximos senão em uma espécie de distância" (Merleau-Ponty 13, p.275).

O problema está em que a verdade do poder só é dada por quem não está no poder, e isto, porque o poder não vê a imagem de si mesmo que é oferecida aos outros. Todavia, não podemos depreender daí que, então, é preferível enganar a fazer o bem. Ora, as qualidades do príncipe são fixadas em atitudes históricas, elas são "vistas”. É neste contexto que surge o grande exemplo de Maquiavel - César Bórgia - retomado por Merleau-Ponty. ${ }^{9}$ A virtù de Bórgia estaria no fato de que seus atos de poder consistiam em intervenções "em certo estado de opinião que alterava seu sentido". O que é preciso reconhecer, aqui, é o enredo no qual se dá a ação histórica, a qual deve levar em consideração o nó inextrincável existente entre "a distância e o grau de generalidade em que se estabelecem as relações políticas" (Merleau-Ponty 13, p.274). Os atos de poder

"despertam um eco às vezes desmedido; eles abrem ou fecham fissuras secretas no bloco do consentimento geral e começa um processo molecular que pode modificar o curso inteiro das coisas. Ou ainda: como espelhos dispostos em círculo transformam uma pequena chama em um espetáculo feérico, os atos de poder, refletidos na constelação das consciências, se transfiguram, e os reflexos destes reflexos criam uma aparência que é o lugar próprio e, em suma, a verdade da ação histórica" (Merleau-Ponty 13, p.273).

Para que o príncipe tenha conhecimento dos ecos que suas falas e atos despertam nas outras pessoas ele deve preservar uma distância que não é diferença absoluta, mas também deve resguardar uma proximidade que não é coincidência completa. Ele deve manter "contato com as testemunhas das quais ele mantém todo o ser poder" (MerleauPonty 13, p.274). Donde a importância de que ele se mantenha livre em relação a suas qualidades podendo, no limite, mudar de conduta quando necessário. O príncipe "precisa, portanto, ter o espírito preparado para voltar-se para onde lhe ordenarem os ventos da fortuna e as variações das coisas, e não se afastar do bem, mas saber entrar no mal, se necessário" (Maquiavel 9, p.85). Agindo assim, o homem político terá o reconhecimento daqueles que governa, pois seus atos fazem parte de um mundo que ele habita. Seus atos estão estreitamente relacionados com o olhar de outrem. Assim, ainda que este homem precise usar a força ou a violência, ela não será uma pura técnica do uso da força, pois "não se pode propriamente chamar virtù o fato de assassinar seus concidadãos, trair amigos, não ter fé, piedade nem religião. Deste modo pode-se adquirir poder, mas não a glória" (Maquiavel 9, p.38). Com efeito, o homem que se envereda nos negócios humanos procura, sim, a glória e a fama, as quais devem aparecer, ser vista e se fazer ver. O discurso sobre os valores deve sempre estar relacionado com sua serventia, eficácia e utilidade social ou cívica. Trata-se, portanto, de agir politicamente no mundo das aparências, pois, nele, o que conta é o que aparece e, além disto, o valor mais alto decorrente da relação com outrem é a glória, ápice das aparências. 
Se a relação com outrem é compreendida como signo de valor na política, é preciso, então, matizar com cuidado a relação de rivalidade advinda da necessidade de exercer ou sofrer constrangimento. Merleau-Ponty dirá que "a vida coletiva é o inferno" (Merleau-Ponty 13, p.268). Para Maquiavel, a luta se dava graças à divisão interna à própria sociedade. "Pois, em todas as cidades, existem esses dois humores diversos que nascem da seguinte razão: o povo não quer ser comandado nem oprimido pelos grandes, enquanto os grandes desejam comandar e oprimir o povo" (Maquiavel 9, p.43). Ora, a luta é a própria realidade do convívio humano nas cidades, cabendo ao homem político a tentativa de unificar e procurar, para as cidades, uma identidade. Donde a necessidade que Maquiavel via de substituir o combate com a força pelo combate com as leis e com o poder (cf. Maquiavel 9, p.83). Dada a divisão social originária entre os grandes e o povo, Maquiavel procurava um príncipe que pudesse unificar a Itália inteiramente fragmentada. Os "novos príncipes" são estes homens que do interior da própria sociedade deveriam tomar e manter o poder, ou melhor, eles deveriam fundar estes novos sistemas chamados "monarquias" ou "repúblicas", os quais assinalavam a importância crescente tanto daquilo que era secular contra a predominância da política teológica, quanto da nação, ponto que excluía a intromissão de outros países. O príncipe deveria fundar um Estado que unificasse e libertasse a Itália. O chefe preconizado por Maquiavel tinha uma tarefa a cumprir: introduzir este novo sistema, afinal, "Deus não quer fazer tudo, para não nos tolher o livre-arbítrio e a parte de glória que nos cabe" (Maquiavel 9, p.124).

$\mathrm{Na}$ interpretação de Merleau-Ponty, a luta deve ser encaminhada para outra direção que o simples antagonismo. Na verdade, a verdadeira violência está no terror causado pela política feita a partir de princípios que estabelecem uma homogeneidade que não tem equivalentes com a realidade do mundo humano. Seria preciso, então, pôr em relevo o "circuito entre eu e outrem" que é o próprio nó da vida coletiva. Ora, na relação com outrem "estamos longe das relações de pura força que existem entre os objetos" (Merleau-Ponty 13, p.268). Por isto, por um lado, outrem nunca poderá ser considerado como puro e simples objeto sob pena de exercermos sobre ele a maior violência de todas. Por outro, é preciso compreender que esta espécie de violência se repetiria se abordássemos a relação entre as pessoas no puro nível subjetivo. Assim, tanto as relações humanas quanto as relações dos sujeitos com o poder "se atam mais fundo do que o juízo" (Merleau-Ponty 13, p.269). Se a constituição do corpo político é feita de conflitos e lutas entre os agentes, a sociedade concreta e real é que passa a chamar atenção, pois ela é susceptível ao tempo. Quando os conflitos e as lutas são inevitáveis, eles devem ser interrogados no sentido de que tragam algo de positivo para o desenvolvimento das relações humanas e das cidades; eles devem ser explorados na perspectiva da convivência possibilitada por boas instituições.

Se o combate por intermédio do poder é preferível ao combate com a pura força, como caracterizar o poder? Ele não é nem "força pura", nem "honesta delegação das vontades individuais"; ele é sempre contestável e está sempre sob ameaça. Como não existe poder absolutamente fundado - não existe fundamento que seja nem anterior, nem exterior à política, seja ele divino, natural ou racional - só existe uma "cristalização do poder". E isto, porque o poder é da ordem do "tácito", o que significa que a opinião tolera o poder e que ela o toma como adquirido: o poder legítimo é aquele que evita o desprezo e o ódio. Mas se o poder não é "puro fato", nem "direito absoluto", ele nem coage, nem persuade, mas "circunscreve - e circunscrevemos melhor apelando à liberdade do que aterrorizando" (Merleau-Ponty 13, p.269). Ora, os benefícios de uma filosofia política deste gênero são muitos. Primeiramente, porque Maquiavel nos introduz "no meio próprio da política e nos permite medir a tarefa se nós queremos encontrar aí alguma verdade" (Merleau-Ponty 13, p.269). Além disto, ele nos "mostra um começo de humanidade emergindo da vida coletiva como que à revelia do poder" (Merleau-Ponty 13, p.27071). Vem daí que Maquiavel, segundo Merleau-Ponty, tenha indicado as "condições de uma política que não seja injusta", a saber: aquela que contenta os povos. O príncipe deve estar do lado do povo e não dos seus rivais. Por quê? Porque "o que engrandece as cidades não é o bem individual, e sim o bem comum” (Maquiavel 10, p.187). Assim, os objetivos da política devem passar longe dos princípios racionais da justiça e da ética, ambos pautados pela tradição de cunho teológico-político. É deste modo que o secretário florentino nos ajuda a não renunciar a virtù compreendida como "um meio de viver com outrem" (Merleau-Ponty 13, p.271). Está aí o caráter intersubjetivo da virtù, pois neste patamar ela consistiria na capacidade do príncipe de se dirigir aos seus subordinados com o objetivo de colocar alguma transparência nas relações, mesmo que para isto fosse preciso usar a força ou a violência, ser mentiroso ou astucioso. Todavia, o poder não deve 
estar separado da liberdade, já que ela é precisamente o critério para medir o valor de um regime político. A liberdade exprime uma espécie de ideal novo se contrastada com a situação em que se encontrava o poder dos papas e dos imperadores. Bem entendido, tratase da liberdade republicana que não deve ser posta a serviço dos poderosos, mas do povo. Ora, “o bem comum só é observado nas repúblicas, porque tudo o que é feito, é feito para o seu bem, e mesmo que aquilo que se faça cause dano a um ou outro homem privado, são tantos os que se beneficiam que é possível executar as coisas contra a vontade dos poucos que por elas sejam prejudicados" (Maquiavel 10, p.187). Compreende-se, portanto, que é a liberdade expressa tanto nas instituições, quanto nas ações e no espírito de conquista que faz a grandeza de uma cidade e de um povo. Alem disto, somente aqueles valores que nascem do contato dos homens com as necessidades da vida pública e se conservam graças aos costumes do povo é que devem ser cultuados. Donde o interesse de Maquiavel recorrer aos exemplos dos Antigos, pois ao invés de venerarem valores de uma ética cristã fundada tanto na revelação quanto na consciência, eles cultivavam os valores cívicos fundados tanto no respeito ao bem público quanto às leis da pólis.

"Se Maquiavel era republicano, é porque ele encontrou um princípio de comunhão. Ao colocar o conflito e a luta na origem do poder social, ele não quis dizer que o acordo fosse impossível, ele quis sublinhar a condição de um poder que não seja mistificante, e que é a participação em uma situação comum" (Merleau-Ponty 13, p.272).

Passemos, então, ao segundo grande momento do texto de Merleau-Ponty: a virtù presente na relação com a fortuna. Desde o início do texto ele dizia que, em geral, as pessoas não gostam de Maquiavel por ele ser um “pensador difícil e sem ídolos” (MerleauPonty 13, p.267). Só que, além disto, aquilo que o torna incompreensível é o fato de que ele une extremos que, tradicionalmente, são excludentes. Ele une incompossíveis, pois "une o sentimento mais agudo da contingência ou do irracional no mundo com o gosto pela consciência ou pela liberdade no homem" (Merleau-Ponty 13, p.275). Do ponto de vista maquiaveliano, são tantas as reviravoltas que a história se encarrega de dar que não é possível atribuir a ela algo que a "predestine a uma consonância final” (Merleau-Ponty 13, p.275). Isto acontece porque Maquiavel "evoca a idéia de um acaso fundamental, de uma adversidade que a furtaria ao poder dos mais inteligentes e dos mais fortes" (MerleauPonty 13, p.275). Mas graças a quê Maquiavel exorciza este "gênio maligno"? Ora, em princípio, para ele o príncipe não é aquele personagem de caráter rígido e constante, assim como a fortuna também não é a encarnação da inconstância. Em seguida, não é se valendo de nenhum princípio transcendente que ele exorciza este gênio maligno, "mas por um recurso aos dados de nossa condição" (Merleau-Ponty 13, p.275-76). Em nossa condição de seres humanos há muita coisa que está em nosso poder, mas há, com certeza, mais coisas ainda que escapam ao nosso poder, o que determina de maneira radical a vida e a ação. Apesar desta imensa adversidade, Merleau-Ponty insiste que em Maquiavel há algo a mais, pois ainda que a força adversa seja bastante poderosa, "não podemos limitar em parte alguma o nosso poder" (Merleau-Ponty 13, p.276). Não se trata de "supor nas coisas um princípio hostil". É verdade que os acontecimentos nos reservam surpresas, como foi o caso de Bórgia, mas nós não devemos fazer vista grossa nem para o nosso próprio corpo, nem para a consciência, nem para a tentativa de previsão. Assim, é o próprio secretario florentino que nos diz que "já que o nosso livre-arbítrio não desapareceu, julgo possível ser verdade que a fortuna seja árbitro da metade de nossas ações, mas que também deixe a nosso governo a outra metade ou quase" (Maquiavel 9, p.119).

Ora, ter um livre-arbítrio, aqui, significa ter uma virtù que dá corpo à ação livre. Já a fortuna "só toma figura no momento em que renunciamos a compreendêla e a querê-la" (Merleau-Ponty 13, p.276), ou seja, quando renunciamos à ação. Mas compreender e querer a fortuna exige certas condutas, como, por exemplo, quando the opomos algumas barreiras; mas, mesmo assim, quando ela vem, ela atinge, precisamente, os pontos vulneráveis. Uma das teses mais impressionantes de Maquiavel consiste em que a fortuna é ora favorável ora desfavorável. A conseqüência desta variabilidade está em que o homem ora compreende ora não compreende seu tempo, "e as mesmas qualidades trazem-lhe conforme o caso o sucesso e a perda, mas não por acaso" (MerleauPonty 13, 276). A virtù do príncipe deve ser encontrada no modo como ele responde às circunstâncias, isto é, se age sempre do mesmo modo e segundo princípios imutáveis ele estará fadado ao fracasso. Mas se for flexível e mudar de acordo com as circunstâncias, ele poderá, na ocasião oportuna, apanhar a fortuna, dominá-la e contrariá-la de acordo 
com suas intenções, momento em que ela lhe será favorável. O príncipe não poderá fiarse unicamente na fortuna, pois se ela mudar ele estará arruinado. Donde Maquiavel dizer que "é feliz aquele que combina [ou ajusta] o seu modo de proceder com as exigências do tempo e, similarmente, que são infelizes aqueles que, pelo seu modo de agir, estão em desacordo com os tempos" (Maquiavel 9, p.120). A variabilidade da fortuna deve estar de acordo com a obstinação da própria maneira de ser do príncipe, pois se não houver este acordo o resultado será a infelicidade. Para Maquiavel é melhor ser impetuoso do que prudente, pois quem é prudente não chega nem a dominar, nem a contrariar a fortuna. É desta espécie de agentes ferozes e audaciosos dominadores que a fortuna é amiga e se oferece como presente. Eis o único recurso indicado por Maquiavel, segundo MerleauPonty:

"a presença a outrem e a nosso tempo que nos faz encontrar outrem no momento em que renunciamos a oprimi-lo, - encontrar o sucesso no momento em que renunciamos à aventura, escapar ao destino no momento em que compreendemos o nosso tempo" (Merleau-Ponty 13, p.276).

Merleau-Ponty indica que há algo que dá "valor absoluto a nossa virtù", a saber, a idéia de que a "humanidade é fortuita" e de que "não tem causa ganha". Isto não quer dizer que a virtù não encontre limites, pois tanto o agente que insiste na ação ineficaz quanto o próprio mundo na sua constante mudança impõem um limite a ela. Mas, se assim for, como antecipar aquela imensa força adversa? "Quando compreendemos o que, nos possíveis do momento, é humanamente válido, os signos e os presságios não faltam nunca" (Merleau-Ponty 13, p.277). Vem daí a importância de saber aproveitar a boa ocasião, momento em que o príncipe se torna um explorador do campo dos possíveis. Em um pequeno texto chamado "Capítulo da ocasião", Maquiavel nos diz que a ocasião não parece uma deusa mortal, os céus a ornaram e a encheram com suas graças, além disto, seu vôo é muito rápido, ela tem asas nos pés que servem para ofuscar os homens. Poucos a conhecem, e é por isto que ela se agita tanto e tem sempre um pé sobre a roda. Ela se apresenta de tal modo que quando surge, não a reconhecemos. Aquele que se perde observando seus detalhes a deixa passar, ou ainda, quando ela dá as costas para alguém, estes só se fatigam querendo agarrar-lhe. Enfim, quem corre atrás dela é o arrependido, pois quem não sabe apanhá-la, só guarda remorso. É neste sentido que precisamos saber aproveitar os signos e os presságios para não nos arrependermos de não ter aproveitado os possíveis do momento oportuno, ou melhor, de não termos explorado o campo dos possíveis (cf. Maquiavel 11). ${ }^{10}$

Segundo Merleau-Ponty, não há nenhum humanismo mais radical do que o de Maquiavel, pois ao contrário de ignorar os valores, ele viu os próprios valores de maneira viva e sempre em transformação, afinal, os valores estão irremediavelmente ligados a certas ações históricas. É preciso, portanto, exorcizar a política feita a partir de princípios, pois uma vez que os princípios fossem aplicados em certas situações julgadas favoráveis eles se tornariam instrumentos de opressão. Não basta tomarmos consciência de quais são os princípios que foram escolhidos, além disto, é preciso saber quais forças e quais homens os aplicam. É verdade que Maquiavel não dispensava os valores, o que por si só também não basta e seria mesmo perigoso nos determos aí. O que fazer então? "Enquanto não se escolherem aqueles que têm a missão de sustentá-los na luta histórica, nada se fez" (Merleau-Ponty 13, p.279). Merleau-Ponty chama atenção para o fato de que sempre numerosos assassinatos e horríveis crueldades foram cometidos tanto em nome da lei quanto em nome da liberdade e, "bem entendido, a dura sabedoria de Maquiavel não as reprovará por isto" (Merleau-Ponty 13, p.279). Quanto a Merleau-Ponty, este ponto merece bastante atenção porque seria preciso ver que, ainda assim, “os meios permanecem sanguinários, impiedosos, sórdidos" (Merleau-Ponty 13, p.279).

Surge, então, um ponto de discórdia com Maquiavel, pois para evitar as barbáries tão conhecidas seria "preciso quebrar o círculo" (Merleau-Ponty 13, p.279). Sobre este ponto é que Merleau-Ponty pensa ser não só possível, mas também necessário uma crítica a Maquiavel. O problema está em que Maquiavel "se contentou em evocar em poucas palavras um poder que não seria injusto, ele não procurou muito energicamente uma definição" (Merleau-Ponty 13, p.280). Merleau-Ponty não diz que Maquiavel estivesse cego para isto. Ele foi, sim, "desencorajado" porque ele "acreditava que os homens fossem imutáveis, e que os regimes se sucediam em ciclo" (Merleau-Ponty 13, p.280). ${ }^{11}$ O que o faz pensar que só existem dois tipos de homem: os homens comuns que vivem o comum da vida e com os quais Maquiavel passou grande parte de seu tempo, e os grandes homens que fazem a história, ou melhor, a interrogam e lhe respondem. Ora, o pomo 
da discórdia consiste em que, por um lado, Maquiavel via muita cegueira nos homens e, por outro, ele também via uma arte natural de comandar destinada a poucos. Tudo se passa como se Maquiavel ficasse tentado a pensar que "não há humanidade, mas homens históricos e pacientes"; mas, além disto, o próprio Maquiavel teria se contentado em se colocar do lado daqueles homens comuns. Donde sua postura de não ter preferência por nenhum "profeta armado"; poderia ser um, mas também poderia ser outro, o que o levava a agir de maneira muito incerta.

"A conduta de Maquiavel acusa o que faltava a sua política: um fio condutor que lhe permitisse reconhecer, entre os poderes, aquele do qual houvesse algo de válido a esperar, e elevar decididamente a virtù acima do oportunismo" (Merleau-Ponty 13, p.281).

Merleau-Ponty não reduz a filosofia de Maquiavel ao cinismo que nega os valores, apesar de que ele escreva contra os bons sentimentos em política, mas ele também não reduz seu pensamento a uma espécie de crueldade, pois Maquiavel também é contra a violência. Merleau-Ponty quer ser justo e indulgente com Maquiavel, pois para ele "a tarefa era difícil” (Merleau-Ponty 13, p.281). ${ }^{12}$

Depois da crítica, Merleau-Ponty elogia o "humanismo sério" de Maquiavel, o qual consiste em esperar, "através do mundo, o reconhecimento efetivo do homem pelo homem". Este humanismo deve ser contemporâneo ao esforço que a humanidade deve empreender para forjar meios de comunicação e de comunhão (cf. Merleau-Ponty 13, p.281). Mas o problema posto por Maquiavel não foi resolvido. O problema de um humanismo real foi retomado por Marx. Segundo Merleau-Ponty,

"Marx se propôs, precisamente, para fazer uma humanidade, encontrar um outro apoio do que aquele, sempre equívoco, dos princípios. Ele procurou na situação e no movimento vital dos homens mais explorados, mais oprimidos, mais desprovidos de poder, o fundamento de um poder revolucionário, ou seja, capaz de suprimir a exploração e a opressão. Mas ficou claro que todo o problema era de constituir um poder dos sem-poder" (Merleau-Ponty 13, p.281).
Donde a alternativa que se impunha entre, por um lado, a possibilidade do poder do proletariado acompanhar a flutuação da consciência de massa e assim ser esmagado, e, por outro, se subtrair à consciência de massa e tornar-se uma nova camada dirigente. O que, aliás, foi o que aconteceu. Merleau-Ponty chama a atenção para o fato de que a solução só poderia ser encontrada em uma "relação absolutamente nova com os sujeitados" (Merleau-Ponty 13, p.282).

"Seria preciso inventar formas políticas capazes de controlar o poder sem o anular, seria preciso chefes capazes de explicar aos sujeitados as razões de uma política, e de obter deles próprios, se fosse necessário, os sacrifícios que o poder lhes impõe ordinariamente" (Merleau-Ponty 13, p.282).

Ora, estas formas políticas foram esboçadas e estes chefes apareceram na revolução de 1917. Mas, “desde a época da Comuna de Kronstadt, o poder revolucionário perdeu o contato com uma fração do proletariado, todavia experimentada, e, para esconder o conflito, ele começa a mentir" (Merleau-Ponty 13, p.282). ${ }^{13}$ Assim, neste contexto, quando há divergência e oposição partidária é porque se trata de sabotagem e espionagem, donde o reaparecimento no interior da revolução das próprias lutas que ela procurou ultrapassar. Isto se dá porque "todo poder tende a se 'autonomizar"” (Merleau-Ponty 13, p.282). Daí aquilo que Merleau-Ponty chama de "o problema essencial": como compreender esta autonomização do poder ligada tanto a um "destino inevitável em toda sociedade" quanto a uma "evolução contingente"? Na época em que a "Nota sobre Maquiavel" foi escrita, o expediente de Kronstadt já havia se tornado "sistema" e o poder revolucionário também já havia sido determinantemente "substituído pelo proletariado como camada dirigente, com os atributos de potência de uma elite incontrolável" (Merleau-Ponty 13, p.282). É neste contexto que sua conclusão pode ser compreendida, pois, "cem anos depois de Marx, o problema de um humanismo real permanece inteiro, e, portanto, [devemos] mostrar indulgência para com Maquiavel, que só podia entrevê-lo" (Merleau-Ponty 13, p.282). É preciso, contudo, deixar bem claro o que se entende aqui por humanismo. Não se trata de uma "filosofia do homem interior que não encontra nenhuma dificuldade de princípio nas suas relações com os outros"; também não se trata de uma filosofia que não encontra 
"nenhuma opacidade no funcionamento social e substitui a cultura política pela exortação moral". Portanto, não se trata de uma filosofia que substitua a reflexão sobre o que é o poder e o que é o ser do social e o ser do político por uma reflexão sobre a consciência do poder, do social e do político. Não é neste sentido que devemos interpretar o humanismo de Maquiavel assinalado por Merleau-Ponty. Não se trata de por em relevo a dimensão rarefeita da consciência e de seus princípios no campo político e histórico.

"Mas se chamamos humanismo uma filosofia que afronta como um problema a relação do homem com o homem e a constituição entre eles de uma situação e de uma história que lhes seja comum, então é preciso dizer que Maquiavel formulou algumas condições de todo humanismo sério" (Merleau-Ponty 13, p.283).

\section{III}

Para concluir, notemos que na filosofia de Maquiavel a política deve ser interpretada como "grande política". O que faz da política maquiaveliana uma "grande política"? ${ }^{14}$ A expressão "grande política" é empregada por Claude Lefort para nomear aquela política que "supõe que seja levado em conta uma tarefa inscrita aqui e agora no ser do social" (Lefort 8, p.433). Quando Maquiavel analisa as figuras do despotismo de sua época, ele chega à conclusão de que nestas condições a política se avilta, pois o despotismo é um poder que precisa de constante constrangimento físico. Segundo Lefort, há uma segurança que é tão pouco recomendável quanto a maior insegurança. Tratase daquela segurança que paga o preço de uma sociedade diminuída e de uma política miserável. Já a

"grande política se reconhece pelo fato de conquistar a segurança na insegurança, de mover no espaço agitado da história, de dar ao Entendimento do príncipe poder de virar-se a todos os ventos, de aliar-se às forças contrárias, ao invés de se subtrair a elas, de forçar a Fortuna ao invés de se esconder de seu apelo" (Lefort 8, p.431).

Lefort nos ensina o que é a "grande política" ao procurar nos fazer entender o que é verdadeiramente a segurança e a glória. Em primeiro lugar, há uma segurança que não é "o único fruto do medo", porque, para Maquiavel, não se trata de enfraquecer os súditos, mas, sim, fortificá-los armando-os. Em segundo, há uma glória que "não se alimenta unicamente da fraqueza e da crueldade dos outros", pois se trata, precisamente, de reconhecer na virtù a própria expressão da glória. Enfim, se a "grande política" está inscrita no "aqui e agora do ser social" compreende-se que é a leitura do mundo presente em que vivia que levou Maquiavel "a restaurar a imagem da grande política” (Lefort 8, p.431). Mas se assim for, quem é o príncipe? O príncipe é aquele que

"deve acolher a indeterminação e que, justamente, se ele a faz andar direito, se ele renuncia à ilusória segurança de um fundamento, a ocasião lhe oferece descobrir, na paciente exploração dos possíveis, os signos da criação histórica, e inscrever sua ação no tempo" (Lefort 8, p.432).

\section{REFERÊNCIAS BIBLIOGRÁFICAS}

1. ARONOVICH, P.F. "Vocabulário de termos-chave de Maquiavel”. In: Maquiavel, N. Discurso sobre a primeira década de Tito Livio. Tradução MF, São Paulo: Martins Fontes, 2007.

2. BIGNOTTO, N. “As fronteiras da ética: Maquiavel”. In: Ética. Organização de Adauto Novaes, São Paulo: Companhia das Letras, 1992.

3. Maquiavel. Rio de Janeiro: Jorge Zahar, Editor, 2003.

4. CHAUI, M. "Apresentação do livro de Lefort". In: A invenção da democrática. Os limites da dominação totalitária. Tradução Isabel Marva Loureiro, São Paulo: Brasiliense, 1983.

5. "Notas do tradutor". In: "Em toda e em nenhuma parte". In: MerleauPonty. Os pensadores, São Paulo: Abril Cultural, 1980.

6. CORCUFF, P. "Merleau-Ponty ou l'analyse politique au défi de l'inquiétude machiavélienne". In: Merleau-Ponty. Le philosophe et les sciences humaines. In: Les études philosophiques. Paris: Puf, abril-junho, 2001-2002, p.211.

7. GOLDMAN, E. "Trotsky proteste beaucoup trop". In: Ni patrie ni frontières, $\mathrm{n}^{\circ} .1$, setembro-outubro, 2002; cf. http://kropot.free.fr/Goldman-trotsky.htm.

8. LEFORT, C. Le travail de l'œuvre. Machiavel. Paris: Gallimard, 1972. 
9. MAQUIAVEL, N. O príncipe. Tradução Maria Júlia Goldwasser, São Paulo: Martins Fontes, 2004.

10. Discurso sobre a primeira década de Tito Livio. Tradução MF, São Paulo: Martins Fontes, 2007.

11. "Capitolo de l'occasion". In: Capitoli. In: Euvres completes. Paris: Gallimard, 1952.

12. MERLEAU-PONTY, M. Causeries 1948. Paris: Seuil, 2002.

13. Signes. Paris: Gallimard, 1960.

14._Les aventures de la dialectique. Paris: Gallimard, 1955.

15. Sens et non-sens. Paris: Nagel, 1966.

16. Humanisme et terreur. Essai sur le problème communiste. Paris: Gallimard, 1947.

17.___ Parcours 1935-1951. Lagrasse: Verdier, 1997.

18. Phénoménologie de la perception. Paris: Gallimard, 1945.

19. RENAUDET, A. Machiavel. Études d'histoire des doctrines politiques. Paris: Gallimard, 1942; cf. edição revista e ampliada de 1956.

20. SILVA, F.L. "A história da filosofia em Heidegger e Merleau-Ponty”. In: Educação e filosofia, Uberlândia: V. 5 e 6, nº. 10, 1991, p.85.

\section{"La grande politique" or Merleau-Ponty reader of Machiavelli}

Abstract: This article intends to consider the work of Niccolo Machiavelli from the approach made by Maurice Merleau-Ponty in his text "Note on Machiavelli". In order to do that, we shall present some general aspects of Merleau-Ponty's political philosophy, trying to track the presence of Machiavelli in the work of the French philosopher. We shall also consider the elements which guided Merleau-Ponty's reading of philosophical texts. Regarding Machiavelli's philosophy, we shall try to highlight the aspects that made the Florentine the first modern political thinker, according to Merleau-Ponty. In conclusion, we shall also consider, following Claude Lefort's expression, the aspects that make politics in Machiavelli's thought to be understood as "la grande politique".

Keywords: Merleau-Ponty, Machiavelli, Lefort, humanism, politics.

\section{NOTAS}

1. Merleau-Ponty nos diz que "se Descartes está presente é porque, rodeado de circunstâncias hoje abolidas, atormentado com preocupações e com algumas ilusões de seu tempo, respondeu a esses acasos de tal maneira que nos ensina a responder aos nossos, embora diferentes, e diferentes nossas respostas. [...] Os filósofos de amanhã [...] continuarão a aprender com Leibniz e Espinosa como os séculos felizes pensaram domar a esfinge, dando à sua maneira, menos figurada e mais abrupta, uma resposta aos enigmas multiplicados que ela lhes propõe" (Merleau-Ponty 13, p.199-200).

2. Philippe Corcuff chama atenção para o fato de que na época de Humanismo e terror a leitura de Maquiavel é fortemente tingida com as cores de uma filosofia da história que passa por Hegel e por Marx. Não há dúvidas de que o Hegel de que aqui se trata não é aquele da síntese final, mas aproxima-se daquele Hegel "pensador de uma história aberta à contingência" (cf. Corcuff 6, p.211).

3. Os novos problemas são: os processos de Moscou, os campos de concentração na URSS, a diplomacia de Yalta, a superstição ligada ao marxismo, o futuro da revolução, as lutas anticoloniais, a guerra da Coréia, a invasão da Hungria pela URSS e a repressão da insurreição de Budapeste em 1956.

4. Sobre a "esquerda não-comunista" conferir em As aventuras da dialética páginas 31113; sobre o "novo liberalismo" conferir no mesmo livro páginas 312-13.

5. Não há consenso, por parte dos comentadores de Maquiavel, de uma definição precisa do termo virtù, e isto, porque o próprio Maquiavel não o definiu. Na verdade, ele é um conceito "multifacetado" que só pode ser compreendido no contexto em que foi empregado. Do ponto de vista individual, ele não pode ser interpretado à maneira tradicional, ou seja, como "composto de qualidades fixas, como coragem, sabedoria, justiça, temperança, isto é, das virtudes cardeais" definidas pela herança clássica. A virtù deve ser vista em relação estreita com a ocasião, donde ela não ser nem um "modo fixo de agir", nem estar "relacionada necessariamente ao resultado final da ação". Do ponto de vista republicano, "tanto o povo como o cidadão e o cidadão-soldado podem ter virtù". Mas também aqui ela não deve ser lida à maneira tradicional. Na verdade, ela "está voltada para a defesa e a exaltação da pátria e para o amor pela defesa da liberdade" (cf. Aronovich 1, p.470-71).

6. O único intérprete da obra de Maquiavel que Merleau-Ponty cita é Augustin Renaudet (cf.Renaudet 19).

7. A propósito desta maneira de interpretar uma obra de filosofia, vale a pena consultar a Primeira e a Sexta Parte do livro de Claude Lefort sobre Maquiavel. Ele compreendeu que ler Maquiavel, ou melhor, interpretar ou interrogar sua obra é perceber que a obra “conserva a virtude de fazer falar" (Lefort 8, p.44). Marilena Chaui nos diz que esta “concepção generosa" de leitura apresentada por Lefort é compartilhada por MerleauPonty. Para ambos "a obra instaura um modo de existência como diferença interna entre escrita e leitura que abre o pensar, em vez de fechá-lo sobre si mesmo, abertura que é o trabalho da obra ou o que Lefort designa como trabalho de interrogação que 'é o vínculo mais seguro entre autor e leitor', pois “é na leitura que um livro se faz”" (Chaui 4, p.13). 8. Maquiavel não é um pensador que funda uma nova visão política que estaria distante de considerações de ordem moral. Não se trata, para ele, de uma legitimação de uma 
política que despreze os paradigmas éticos, os quais seriam absolutamente independentes da política. Para este filósofo não há ruptura absoluta entre ética e política. Há, sim, muitos aspectos éticos em seu pensamento. Não se trata, contudo, de regular as ações políticas segundo leis de uma moral abstrata. Newton Bignotto nos ensina que "falar de representações não implica dizer que a ética não tem ligação com a política". Falar de representações equivale a mostrar que "a ética, vivida como costume, é a janela através da qual percebemos as ações humanas, sem que isso explicite a verdade ou não das proposições que nos guiam e revele a essência dos atos julgados". Portanto, a política não pode afastar-se totalmente da ética, afinal, ela "depende da representação que os homens fazem dos atos dos governantes", o que assegura, justamente, "um lugar para ela na vida pública". Além de criticar a ética abstrata dos moralistas, Maquiavel, ao mesmo tempo, "atribui outra função aos julgamentos morais" e exige "outro sistema de valores, mais apto a fazer-nos entender a política". Quando ele faz de Roma a "encarnação dos mais elevados parâmetros políticos, que toda ação deve guiar-se pelas ações de seus grandes homens", trata-se de compreender que há uma "exemplaridade da cidade que se funda na exemplaridade da ação dos seus cidadãos". É a liberdade que faz de Roma o melhor exemplo possível para um regime político. "É a liberdade, expressa nas instituições, nas ações, no espírito de conquista, que faz de Roma o modelo a ser imitado. [...] Escolher Roma como exemplo, fazer de suas instituições o modelo a ser imitado, implica abandonar o universo cristão de valores e, assim, negar que a ação política possa ser julgada pela 'moralidade' dos atores. [...] Maquiavel não opõe duas esferas autônomas da ação - a política e a ética - mas opõe duas maneiras de se conceber a ética: uma cristã, fundada na revelação e na consciência, e outra antiga, fundada no respeito ao bem público e às leis da pólis. Essa verdadeira revolução só foi possível porque o humanismo havia preparado o terreno para o culto dos valores cívicos". No universo moral dos antigos e em parte dos renascentistas, "a verdadeira ética nascia do contato dos homens com as exigências da vida pública e se conservava pelos costumes do povo". Maquiavel "afirma, sem ambigüidade, a superioridade da antiga ética sobre a do seu tempo, mantendo a discussão no terreno próprio ao debate sobre os valores". Por fim, o debate de Maquiavel se dá "no universo de uma ética-política, ou de uma política que carrega em si um corpo de valores diferentes daqueles de uma moral da consciência" (cf. Bignotto 2, p.113-125).

9. Bórgia - exemplo de governante para Maquiavel - era grande dissimulador de seus pensamentos e de sua natureza íntima. Exemplo de sagacidade política, Bórgia ocupou o poder em uma situação favorável no início, mas permaneceu no poder mesmo quando a situação tendia a complicar-se. Ele é "um modelo para todos os que pela sorte ou pela força dos outros chegou ao poder": hábil para lidar com situações extremas, ele foi um personagem cruel e ambíguo. Tornou-se um exemplo a ser seguido por todos aqueles que desejam o sucesso na vida política. Porém, não pôde sair do aperto em que se viu quando além de cair doente, o seu pai - o papa Alexandre VI - morreu. Mesmo sendo alguém que soube aproveitar a ocasião oportuna, não pôde resistir à fortuna. O ponto importante está em que para Maquiavel não há um poder que dure para sempre: "nada é mais constante do que essa verdade: tudo o que existe no mundo tem limite em sua duração". "As coisas humanas resistem apenas o tempo que lhes é possível, sendo em seguida corrompidas pelo efeito de sua própria natureza. [...] Em sua obra, Maquiavel prefere sempre os exemplos dos que enfrentam as dificuldades do mundo, mesmo que saiam derrotados no final" (Bignotto 3, p.23).

10. Para vermos com uma lente de aumento o momento específico da relação ou da ligação entre a fortuna e a virtù - conceitos que sempre devem ser considerados juntos -, não podemos pura e simplesmente considerar a fortuna como uma força terrível e sempre destruidora, conduta que conduziria o agente ao desespero completo e o levaria ao desconhecimento da relativa racionalidade das ações. Na verdade, este ponto de vista é, no limite, fatalista e não deixa nenhuma margem à esperança. Ora, esta postura é tornada impossível pela própria análise que vê na fortuna uma força que não nos permite conhecer suas tramas. "Resta sempre uma esperança e ela deve nos conduzir a agir e a enfrentar os perigos que aparecem, exatamente porque nenhum cálculo racional será capaz de prever todos os movimentos que se seguirão ao aparecimento das garras da fortuna, inclusive aqueles que serão benéficos aos nossos desejos. A palavra esperança pode soar estranha no contexto de uma discussão sobre a contingência do mundo da política, mas ela é a ponte entre virtù e fortuna, fundamentais no pensamento de Maquiavel para se examinar a ação política" (Bignotto 3, p.27-28).

11. Dizer que os homens são imutáveis é o mesmo que dizer que eles repetem suas paixões e sua forma de agir: "a natureza humana é repetitiva e, portanto, pode ser analisada em qualquer tempo com as mesmas ferramentas" (Bignotto 3, p.14). Dizer que os regimes se sucediam em ciclo é afirmar "a crença de que o tempo era circular e as formas políticas iam se revezando à medida que ele transcorria" (Bignotto 3, p.54). Mas Maquiavel também estava certo de que a marcha do tempo é que desencadeava a corrupção dos regimes.

12. A situação política da sua época exigia alguém que pudesse governar a Itália e soldados para realizar este objetivo. Donde as questões que Merleau-Ponty nos põe: "Na discordância de uma Europa que se ignorava, de um mundo que não havia feito seu inventário e onde os países e os homens dispersos ainda não haviam cruzado o olhar, onde estava o povo universal que pudesse se fazer cúmplice de uma cidade popular italiana? Como os povos de todos os países teriam se reconhecido, entendido e unido?” (MerleauPonty 13, p.281).

13. A Comuna de Kronstadt - da cidade de Kronstadt na Rússia - deve ser considerada 
a última tentativa do proletariado russo de colocar a Revolução em seu antigo eixo. A revolta ocorrida em 6 de março de 1921 denunciava a predominância do partido único e exigia a eleição livre de representantes das massas trabalhadoras. É em relação a certa fração do proletariado (marinheiros, soldados, operários e camponeses) que o poder revolucionário já tinha, naquela época, perdido contato. A palavra de ordem dos revoltosos era: "viva os sovietes e abaixo os comunistas" do partido bolchevique. A revolta foi totalmente massacrada. Donde Merleau-Ponty afirmar que nesta ocasião o poder revolucionário já havia perdido contato com a grande maioria da população. Eis um trecho da mensagem radiofônica difundida pelos insurretos "aos trabalhadores do mundo inteiro": "Nós somos partidários do poder dos sovietes, não dos partidos. Nós somos pela eleição livre de representantes das massas trabalhadoras. Os sovietes fantoches manipulados pelo partido comunista sempre foram surdos para as nossas necessidades e para as nossas reivindicações; não recebemos senão uma resposta: a metralhadora. [...] Camaradas! Não só eles querem nos enganar, mas eles transvertem deliberadamente a verdade e nos difamam da maneira mais desprezível. [...] Em Kronstadt, todo poder está exclusivamente entre as mãos dos marinheiros, soldados e operários revolucionários. [...] Viva o proletariado e a classe dos camponeses revolucionários! Viva o poder dos sovietes eleitos livremente" (cf. Goldman 7). Emma Goldman cita este trecho em um artigo publicado originalmente na revista Vanguard - de tiragem mensal e editada em Nova York - publicado em julho de 1938.

14. A expressão "grande política" deve fazer eco à expressão merleau-pontiana "grande racionalismo". O que vem a ser o "grande racionalismo"? Em princípio vale observar que Merleau-Ponty tinha a intenção expressa de retomar de maneira mais radical "a tarefa que aquele século intrépido [século XVII] acreditava ter cumprido para sempre” (MerleauPonty 13, p.191). Merleau-Ponty recusa do "pequeno racionalismo" a explicação do ser pela ciência. Contra esta postura, é interessante voltarmos nossa atenção para aqueles pensadores do século XVII, momento privilegiado, rico de uma "ontologia viva". Eles não tomavam os resultados da ciência como cânon da ontologia, na verdade, eles admitiam que a filosofia se projetasse sobre a ciência "sem ser sua rival": o objeto da ciência era considerado apenas um "grau do Ser" e se justificava "em seu lugar". Além disto, as filosofias deste século concebiam um "acordo extraordinário entre o exterior e o interior" graças à mediação do "infinito positivo", espécie de segredo do "grande racionalismo". Neste ponto, os trabalhos deste século estão bem longe daquilo que pensamos de nossa situação filosófica atual que, segundo Merleau-Ponty, tem como tema favorito a "contingência do mundo". Na verdade, é preciso frisar que esta contingência vem trazer a exigência de se pensar de modo diferente a coesão do todo. Se o "infinito positivo" levava à recusa da ambigüidade e da temporalidade era porque os pensadores deste século se embasavam nas idéias de identidade e de eternidade. Ora, desde que se reconheça a historicidade do saber, nem o mundo, nem o saber sobre o mundo, nem as idealidades, nem as ações poderão ser compreendidas como "desdobramento do fundo idêntico e eterno através da duração finita do homem” (Chaui 5, p.229). Será preciso, ao contrário, que a historicidade surja como "produção", ou seja, como trabalho humano. Compreende-se, portanto, que Merleau-Ponty diga que "a novidade da fenomenologia" não consista em negar a "unidade da experiência", mas "fundá-la de outro modo que o racionalismo clássico" (Merleau-Ponty 18, p.340). Seja como for, o importante a ser frisado está na inscrição do infinito no próprio coração da experiência, e não em Deus ou na consciência. 